\title{
From Voluptuous Woman to Porky Butterball: The Rise and Fall of the Voluptuous Woman Ideal
}

Julie Dinh

This paper examines the rise and fall of voluptuousness as a beauty ideal in midnineteenth century America. It argues that the rise and fall of the fuller figured woman can be traced to shifting economic, social, and medical beliefs that in turn, affected perceptions about fatness' relationship to class, morality, health, and beauty.

After noticing a portrait of an unknown woman in 1912, a little girl innocently asked her mother, "Who is that fat lady?" Much to the dismay of her mother and the adults who overheard her, she was actually referring to Lillian Russell, America's most iconic beauty and body only a few decades earlier. ${ }^{1}$ In her heyday, Russell had been touted as the epitome of American beauty and had been greatly admired for her voluptuous figure, making this innocent offhand description of her as 'fat' in later years a good indication of how the perception of fat had changed dramatically from the mid nineteenth century. In fact, this is only one example of how the standards of beauty have been in flux throughout the generations. ${ }^{2}$

My goal here is to look further than the aesthetic changes that occur and analyze how the evolution of beauty standards tells a much broader story than what meets the eye. Although this idea applies to a plethora of eras and ideals, I will focus on the 'voluptuous woman' ideal of the mid-1800s to early 1900s. What were the main factors that contributed to the rise and subsequent decline of this body ideal? In other words, why was her plumpness attacked after being celebrated for an entire generation? In response, I argue that while the economic, social and medical beliefs of the mid nineteenth century was suited for her rise, by the turn of the century, changing values and shifting perceptions of class, morality, economy and medicine were in direct conflict with her 'fat' body, thereby leading to her downfall. Although I address these issues separately, these factors should be understood as interrelated, building and reacting off of one another other to create a larger complex and coherent picture - in other words, there is no one reason for her rise or decline. Firstly, I will analyze how and why the economic and social environment of the 1800s nurtured the image of a full figured body. Subsequently, these same factors, or perceptions of these factors, will be shown to have shifted significantly by the late 1800 s along with the introduction of new ideas that combined together to successfully push the voluptuous woman ideal out of mainstream.

The voluptuous woman ideal was, in large part, a class and status-heavy phenomenon. While there had been, of course, full figured women in all groups of society, the image of the voluptuous woman as an ideal had already existed outside of the mainstream before the mid-1800s, namely in the lower classes, in immigrant groups and in the subcultures of theatre and performance. In turn, the economic growth of the United States in the mid-1800s only increased the visibility of these groups - introducing their standard of beauty to the mainstream public. Firstly, the lower and immigrant classes of the United States linked economic status and class with body weight, where economic hardship and instability equated thinness with scarcity and by contrast then, voluptuousness with

1 Lois Banner, American Beauty (New York: Alfred A Knopf, 1983), 153.

2 For example, Banner argues that between 1800 and 1921, the changing image of the ideal woman can be divided into four distinct eras: the antebellum "steel-engraving lady", the "voluptuous woman" after the civil war, the "Gibson girl" of the 1890s and earlier twentieth century and finally the "flapper" girl throughout the 1920s. Ibid., 5. 
prosperity, wealth and success. ${ }^{3}$ As the economy experienced accelerated growth starting in the 1840s, these groups became more prominent in the middle classes and indulged in the multi-course, heavy meals once enjoyed by only the upper class. Similarly, Stearns, author of Fat History: Bodies and Beauties in the Modern West, argues that fat was also associated with American patriotism. ${ }^{4}$ While the public were equating their personal physique with prosperity, the ability to indulge was also associated with America's prosperity as a whole. Because the British upper class was known for having multi-coursed, heavy meals, the ability for most Americans to indulge in these types of meals was indicative of the United States' success. In other words, by having a hefty population, Americans were proving that theirs was a land of plenty.

Secondly, the voluptuous woman had also already been strongly connected to the subculture of theatre, where curves and flesh were equated with sensuality. Celebration of sensuality, consequently, also increased in this era - allowing for increased popularity of actresses and burlesque dancers as well. Banner, author of American Beauty, argues that "periods of war and their peacetime aftermaths are often characterized by freer behaviour." In other words, post-civil war, Americans were looking for a good time - a change from the moral Victorian era. Thus, the mainstreaming of theatre and burlesque dancing, that were usually associated with being immoral, was not a surprise. Although voluptuous figures did not hold a monopoly over admired actresses and dancers, the huge popularity of some of these figures should be noted. For example, the Thompson troupe, a group of British burlesque dancers, were an enormously popular show that toured the United States for over thirty years.

The role of French salon art also had a significant impact on the rise of the voluptuous woman. While America's economic prosperity allowed for the increase in visibility of lower and working classes, the upper and middle classes of America were also being introduced to the voluptuous woman through higher art. Banner associates the popularization of French art to the 1850s, when Americans' art taste went from cultural nationalism to a growing preference for European art. This was in large part thanks to the growth in wealth of the already wealthy or middle class - whom, Banner argues, simultaneously went through a growth in "cultural sophistication."6 European art, notably French salon art, was now seen as superior and as another status symbol for high class. Although these painters did portray many different types of women's bodies, the running theme throughout the French salon trend was the classical model of the woman - very much so represented by the voluptuous woman. Bouguereau's "Nymphs and Satyr," painted in 1873, is an often celebrated portrait of a voluptuous beauty. Another example of the voluptuous beauty was Fanny Cornforth, a plump prostitute who was often Dante Gabriel Rossetti's muse, whom he described as "the marvellous fleshiness of the flesh."7

Medical beliefs about the body and the benefits of fat also reinforced the voluptuous woman ideal. In his book, Never Satisfied: A Cultural History of Diets, Fantasies and Fat, Schwartz argues that "Why people choose to diet, when they diet, how they go about dieting - these are determined by prevailing fantasies about the body, its weight and its fat." 8 While the social perceptions of fat are undeniably a part of these 'fantasies', medical beliefs at this time were also very influential. By the

\footnotetext{
3 Ibid., 112.

4 Peter Stearns, Fat History: Bodies and Beauties in the Modern West (New York, NYU Press, 2002), 10.

5 Banner, American Beauty, 116.

6 Ibid., 116.

7 Ibid., 111.

8 Hillel Schwartz, Never Satisfied: A Cultural History of Diets, fantasies and Fat (London: Collier Macmillan Publishers, 1986), 4.
} 
1870s, many of the medical sectors in the United States were associating fat with health and thinness with frailty and disease. ${ }^{9}$ The physician, S. Weir Mitchell, argued that "skinny forms correlated with discontented, nervous personalities." and other gendered illnesses, such as hysteria and consumption. Therefore the belief that a heavy body was a healthy body was reinforced by both medical beliefs and public opinions about the body.

A strong example of these ideas comes from the case studies done by Lowe in Looking Good: College Women and Body Image, 1875-1930. Studying three women's colleges, Lowe argues that much of the criticism of female education had to do with medical beliefs of the time. Education, and the consequent stress of studying, was seen as detrimental to the overall health of the female. Society was critical of women's education because there was a widespread belief that college was harmful to the already weaker sex. Because thinness was associated with nervousness, weakness and frailty, the female population at these colleges had to "prove their fitness for academic life by repeated demonstrations of gaining: weight, inches."11 Evidence of this can be seen in the letters that Lowe collected from students to their families, where they eagerly reported their meals and weight. For example, Alice Miller recorded her weigh in great detail, "We are both growing fatter ... We were weighed the other day - Helen weighing ninety-seven and a half pounds and I ninety-eight."12 By doing so, she is reassuring her reader that their bodies were unharmed by their new academic life.

By the 1870s, the voluptuous woman had "come into her own." 13 Although it should be noted that she was neither the only nor most popular body ideal in America, she was nevertheless prominent in all classes of society. In fact, she was widely seen as jolly (an old stereotype), healthy, and sensual. However, two decades later, it seems as though she begins to rapidly decline. In fact, bedroom and bathroom scales began regularly appearing in private homes (a new phenomenon) in the early 1900s. Food scales also became a staple kitchen item by the $1920 \mathrm{~s} .{ }^{14}$ Clearly, as reducing and dieting became more popular, the voluptuous woman's famous hearty appetite began to come into conflict with a new society that encouraged calorie counting and planning. Instead of a clear-cut timeline, however, the fall of the voluptuous woman is both a result of a quickly modernizing society and of very old, already existing attitudes about the body. Although Stearns argues that her downfall can mostly be attributed to a matter of morals, I argue that it was the culmination of these factors (and not simply one sole reason) that led to her downfall.

The backlash against abundance and sin was a key factor in the downfall of the voluptuous woman ideal. For context, society was rapidly changing in the late $1800 \mathrm{~s}$. The economic growth of the United States had levelled off by the end of the century but was still enormously prosperous. In fact, these decades are most commonly associated with overwhelming abundance. In turn, there was a growing anxiousness about the increasingly lost morals of the era that was connected to this economic success. What Schwartz calls a "fear of abundance", and Stearns a "nervous commitment to commercial economy" resulted in a backlash against economic excess and gluttony. Of course,

9 Banner, American Beauty, 113.

10 Stearns, Fat History, 9.

11 Margaret Lowe, Looking Good: College Women and Body Image, 1875-1930. (Baltimore: The John Hopkins University Press, 2003), 29.

12 Ibid., 51.

13 Banner, American Beauty, 127.

14 Lowe, Looking Good, 145.

15 Schwartz, Never Satisfied, 81.

16 Stearns, Fat History, 7. 
the fear of gluttony precedes the 1800 s - and with the excess availability of food came a slippery slope into sin. According to Schwartz, gluttony was the first step into excess of all kinds,

Fed too often because too often temped, fed too ignorantly and therefore never satisfied, children grew weak, anxious and dyspeptic. The same children, appetites corrupted by salt and pepper, the tea and coffee of an overly rich diet, became so accustomed to sensual excitements that self-pollution was the awful but common sequel. Habituated to public gluttony and thus to private lust, young husband and young wife would fall prey to the perils of sexual excess. ${ }^{17}$

On the opposite end of the spectrum, as Stearns points out, was the association of thinness and sainthood. ${ }^{18}$ Furthermore, the sensuality of the voluptuous woman attracted critics who associated her with sexual sin - excess of flesh was again bound to prostitution and pornography. It seems that the voluptuous woman could not entirely escape her lower class roots. Indeed, this was a backlash based on moral grounds, where the status symbol that the voluptuous woman provided earlier in the century had been transformed into a symbol of sin and excess by the start of the next.

New medical beliefs also attacked the image of the voluptuous woman, albeit gradually. One factor that influenced medicine's change of heart was the change in disease patterns between 1880 and 1920. Stearns explains that these decades saw a decline in infant mortality, thereby shifting the concentrated death tolls from the extreme ends of the age scale to the middle. Longer life expectancies meant that medicine now concentrated more readily on degenerative diseases instead of contagious ones. ${ }^{19}$ Although it does seem as though American doctors lagged behind their European counterparts in terms of condemning fat, there were still signs that these ideas were becoming more and more widespread. By the 1880s, "medical authorities on life insurance agreed that those rated up for corpulence were generally 'a very bad class of lives." 20 By the early 1900s, doctors had generally reached a consensus that corpulence needed to be treated. Almost two decades later, Harvey Levenstein stated that "by 1918...the idea that being overweight was unhealthy had caught up with the traditional idea that being underweight denoted poor health.,"21

Attitudes about exercise also changed the perception of the voluptuous woman. Exercise had once been disliked because women were afraid of losing their voluptuous figures. Sports and exercise were also not easily accessible to women. However, paralleling the changing beliefs about the body, exercise had triumphed by the end of the century. Although there were instances when women did engage in sports and exercise pre 1880, it seems as though their performance was usually greatly restricted because of their constricting dress and general disinterest. According to Banner, however, the introduction of tennis, the beginning of athletics in women's colleges, the sudden popularity of the bicycle, and the influential work of exercise advocates were all essential for improving views towards forms of exercise post- $1880 .{ }^{22}$ Interestingly, it was claimed that exercise was a cure for nervousness and tensions - which had been previously linked to excessive thinness. The exercise movement's achievement was to reinforce the athletic body type.

The introduction of home economics both addressed the fear of overabundance and introduced scientific ways of thinking about food that emphasized order and denounced the appetite. Lowe

17 Schwartz, Never Satisfied, 25.

18 Stearns, Fat History, 6.

19 Ibid., 26.

20 Schwartz, Never Satisfied, 89.

21 Lowe, Looking Good, 147.

22 Banner, American Beauty, 142. 
argues that at a time when the voluptuous body was still semi-popular in the early 1900s, home economics "played a prominent role in formulating and answering questions about women's bodies." 23 While keeping the ideas of gluttony as sin and newly formed health ideas in mind, it makes sense that the "new food scientists advocated a rational, businesslike approach to eating rather than the untrained unpredictable, "messy" dictates of the appetite." 24 The new scientific ways of thinking about food (i.e. counting calories) conformed to these ideas. Lowe's research into the home economic programs at the women's colleges shows a clear conflict between students' appetites and their guilt at not following strict food regiments. However, this does show that the relationship between women and food became increasingly defined by conflict - no longer did she celebrate eating for the sake of eating. ${ }^{25}$ In addition, good meal planning and organization was seen as a way of uplifting the poor. Because of the prosperous American economy, Schwartz argued that "pauperism resulted from a disregard for home economics." 26 The introduction of home economics and scientific nutritional beliefs were key factors in how the American public viewed eating and food habits.

As moral accusations of gluttony and scientific accusations of poor health attacked the voluptuous woman's hefty diet, she began to also be bound to inefficiency and awkwardness. Schwartz argues the new kinaesthetic values appeared in the late 1800s and early 1900s that emphasized fluid movement and gracefulness. ${ }^{27}$ Technological advances in flight, new scientific management of industries and, perhaps most importantly, modern dancers all created a new emphasis of efficiency and gracefulness, with their movements critically balanced. Therefore, excess weight was seen as completely the opposite of the ideal body for movement, "an aerodynamic body, curved but slender, controlled but light." 28 The voluptuous body, then, was permanently bound to gluttony, to inefficiency, imbalance, and excess.

As women began to feel more and more self-conscious about their body weight, products that promised slimmer figures began to appear en masse in America's consumerist culture. The advertisement for Allan's Anti-Fat (shown below) is a good example of how advertisers used a combination of medical beliefs and public opinions or stereotypes to sell their product. Although the advertisement first appeared in 1878, this is one example of how history cannot be cleanly divided into neat eras. While the general era of the voluptuous woman ended by the end of the century, the rumblings of her faults began earlier. Firstly, the language used in this advert had an obvious medical spin: The 'patient' needed a 'remedy' for this 'disease', promising 'vigorous and healthy feeling'. On the other hand, the image itself, with the fat lady being stared at by the other thinner women (especially the woman at the very back who is craning her neck to view the fat woman) implies that the fat woman is embarrassed because she seems to be a sort of spectacle. This is telling of the embarrassment and shame that fatness had become. Interestingly, she is also the only woman sitting in the picture - perhaps a subtle nod to the stereotypes of fat people as lazy. Advertisements like this one are not uncommon in this era.

23 Lowe, Looking Good, 8.

24 Ibid., 135.

25 Ibid.

26 Schwartz, Never Satisfied, 84.

27 Ibid., 81.

28 Ibid., 80. 


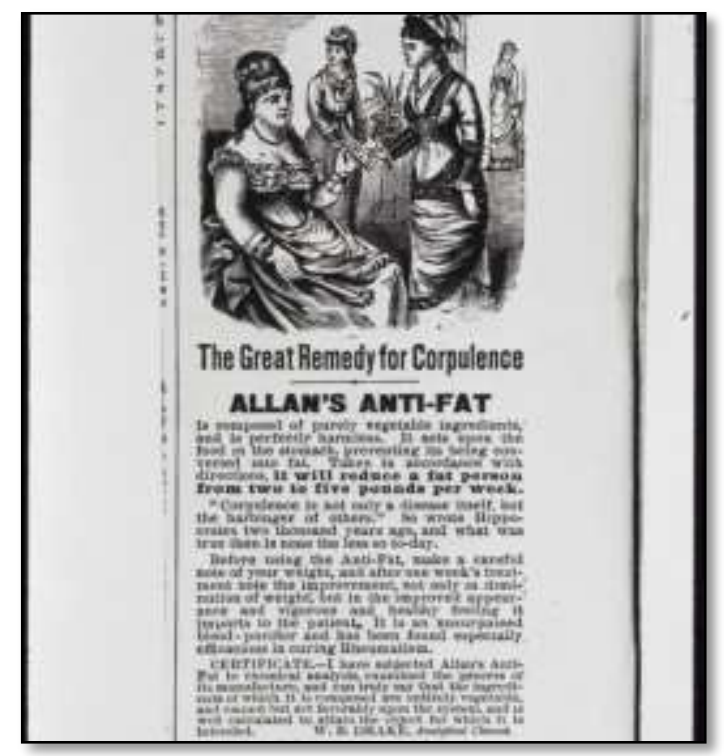

Obesity Advertisement ${ }^{29}$

In hindsight, the rise and fall of the voluptuous woman was a relatively quick one whereas thinness has stayed a beauty ideal until the present. I suspect that the reason for this difference is because the 'fad' of the voluptuous woman came about through specific but more superficial economic and social factors that were dependent on their timing. For example, fatness as a status symbol was reliant on hard economic times and was not a deep-seated value of society. On the other hand, many of the ideas behind thinness were ingrained values that permeated throughout society, such as the fear of sin. Furthermore, the running theme throughout the last decades of the 1800 s and early 1900s was an emphasis on efficiency, balance, organization - all in reaction to the fear of excess as a whole. The strive for efficiency and balance were benchmarks for progress.

In conclusion, the rise and fall of the voluptuous woman as an ideal was due to an amalgamation of several economic, social, and medical factors. Public opinion and stereotypes often reinforced medical and economic arguments for the celebration of her body. That being said, a few decades later, different public opinions and stereotypes also reinforced a new set of medical and economic arguments that were used to attack the body image. The culmination of these factors was devastating for the voluptuous woman. Attacked on several fronts, the voluptuous woman no longer fit at all into mainstream society's values or beliefs and arguably did not stand a chance against the Gibson and flapper girls of the future. The society that had admired and nurtured her body in the mid-1800s had changed dramatically - medical beliefs that had once encouraged her plumpness began to view her body as unhealthy. And even when she was depicted, her sensuality was too firmly tied to pornography for her to be respectable again and her figure as a high-class status symbol was replaced by the perception of her body as inefficient, awkward and slow. 'Voluptuousness' was now replaced with new descriptors such as 'porky', 'butterball', and 'fat slob'. ${ }^{30}$

\footnotetext{
${ }^{29}$ Harper's Weekly. “[Obesity.]” Photograph. 1878. From The National Library of Medicine. <http://ihm.nlm.nih.gov/images/A13089> (accessed November 18th, 2011).

30 Ibid., 89.
} 


\section{Bibliography}

Banner, Lois. American Beauty. New York: Alfred A. Knopf. 1983.

Lowe, Margaret. Looking Good: College Women and Body Image, 1875-1930. Baltimore: The John Hopkins University Press. 2003.

Schwartz, Hillel. Never Satisfied: A cultural History of Diets, Fantasies and Fat. London: Collier Macmillan Publishers. 1986.

Stearns, Peter. Fat History: Bodies and Beauties in the Modern West. New York: NYU Press. 2002. 